DOI 10.31651/2524-2660-2020-2-158-162

ORCID: 0000-0002-5328-7274

\title{
САУцЬкий Ярослав Сергійович,
}

кандидат педагогічних наук, завідувач навчально-методичним кабінетом,

Донбаський державний коледж технологій та управління e-mail: yaroslav.slutskiy.mail@gmail.com

УДК 37:008]:378.091.212-027.63-044.332(045)

\section{ОСОБАИВОСТІ ПОАІКУАЬТУРНОЇ ОСВІТИ У ПРОЦЕСІ АДАПТАЦІЇ IНОЗЕМНОГО СТУДЕНТА}

У статті проаналізовано сутнісні характеристики полікультурної освіти, яка має застосовуватися при сучасних методах адаптаиійної підготовки іноземного студента, який взаємодіє з представниками нового культурного середовища. Виявлено, шо полікультурна освіта проявляється в особливостях взаємозв'язку особистостей, які $\epsilon$ представниками різних мовних, етнічних або наиіональних груп. Розглянуто поняття глобального мислення, шо характеризується здатністю іноземного студента практично застосовувати наявні навички соиіокультурної $і$ міжособистісної діяльності. На основі аналізу висновків дослідників, надано власне трактування понять "полікультурна освіта" та "технологія полікультурної освіти". Для подальшого дослідження підготовчоадаптаиійної системи для іноземних студентів, проаналізовано п'ять факторів полікультурної освіти, спрямованих на ефективну підготовку особистості до академічної та соиіальної діяльності.

Ключові слова: адаптаиія; іноземний студент; полікультурна освіта; акультураиійний проиес; технологія; діяльність академічного та соиіального характеру.

Постановка пробцеми. Інтернаціоналізація освітньої системи передбачає збімьшення кількості іноземних студентів, які проходять навчання в інших країнах, що характеризуються незнайомими дмя особистості соціокультурними нормами. У зв'язку з цим, виникає потреба проведення відповідних адаптаційних процесів, які б дозволики іноземному студентові успішно подолати негативні наслідки культурного шоку, викликані необхідністю регулярної взаємодії з представниками іншого соціуму. Такого роду підготовка повинна включати в себе мінгвістичний, кумьтурний та психологічний емементи, кожен 3 яких $\epsilon$ складовою частиною акультураційного процесу. Дослідження цих елементів, їх особливостей і структурованості має важмиве значення для проведення модернізаційних процесів, спрямованих на розвиток відповідних підготовчих програм.

Аналіз останніх досліджень і публікацій. Проаналізувавши наукову мітературу з проблеми проведення якісно вибудуваного адаптаційного процесу іноземних студентів, можна видікити основні напрями наукових пошуків дослідників, а саме дослідження: проблем, що виникають при взаємодії іноземних студентів з умовами нового соціокультурного простору (К. Йан, К. Девід, М. Патрон, К. Боуман, К. РоузРедвуд, К. Перкінс, Т. Тойокава, К. Саркоді-Менсах та ін.); питання мотивації іноземних студентів до навчання за кордоном (Т. Маццароц, Г. Соутар, Г. Варастех, А. Марцукі, С. Разуміманеш, М. Бейн, Р. Ноец, $\Lambda$. Рагот та ін.); особливостей акуцьтурації іноземних студентів (С. Пойрациі, К. Греем, Дж. Рен, К. Брайан, Й. Мін, Й. Вей, Б. Вардсворт, М. Гехт, Е. Джун, К. Ван, Б. Маммінкродт, К. Доунінг та ін.). Але питання саме помікультурної освіти у форматі поєднання елементів адаптаційного процесу (Аінгвістичної, культурної та психологічної підготовки) не достатньо розгАянуті у науковому просторі.

Мета статті - дослідити особливості помікультурної освіти, спрямованої на підготовку іноземного студента до практичної діяльності академічного та соціального хаpaктеру.

Викмад основного матеріалу досиідження. Адаптаційні програми мінгвістичного, психологічного та культурного супроводу іноземних студентів $\epsilon$ складовими частинами технології полікультурної освіти в закладах вищої освіти США. Однак, для формулювання технологій і проведення аналізу їх практичного застосування в університетах і коледжах, нам необхідно розгцянути термінологічну базу. Так, поняття мультикультурної освіти у Великому психомогічному словнику трактується як "освітня стратегія, яка представцяє послідовні освітні процеси (організація, реалізація, результат)" [1, с. 275]. Отже, ми можемо говорити про те, що полікультурна освіта має вкАючати в себе організаційні заходи (при яких іноземні студенти повинні бути розподілені по групах і отримати індивідуально розроблену освітню програму, сформовану відповідно до адаптаційного плану); реалізацію поставцених завдань (у рамках чого проводяться, власне, практично спрямовані заняття, що мають основною метою зменшення негативного впливу куцьтурного шоку і міжкуиьтурного розриву між представниками різних національнос- 
тей); отримання результату (що передбачає успішне проведення акультураційного процесу та надає можливість іноземним студентам проводити ефективну академічну і соціокультурну діяльність, у тому числі поза межами закладу вищої освіти).

Крім того, Великий психологічний словник зазначає, що "розроблення навчальних програм та організація навчального процесу в рамках стратегії мультикультурної освіти орієнтовані на подолання культурного відчуження учнів" [1, с. 275], що може свідчити щодо необхідності, при створенні та впровадженні адаптаційних програм i заходів, враховувати наявність занять, спрямованих безпосередньо на вдосконамення міжособистісного та міжкультурного контакту між студентами, що передбачає більшу кількість заходів спільного формату, коли представники різних культурних груп повинні співпрацювати для досягнення поставленої мети або перебувати в таких умовах, які будуть забезпечувати невідворотність проведення комунікаційної діяльності.

Таким чином, явище полікультурної освіти характеризується як педагогічний процес, в якому представлені дві (або біньше) культури, що мають відмінні риси за мовними, етнічними, національними або расовими аспектами. Відповідно, полікультурна освіта не може відбутися в монокуиьтурних групах закладів вищої освіти. Тому, при розподікі іноземних студентів важливо враховувати необхідність наявності в кожній із груп представників щонайменше одного культурного спрямування. В іншому випадку, технологія полікультурної освіти не зможе бути практично застосована.

У свою чергу, В. Безрукова в енциклопедичному словнику педагога надає визначення поняття "глобальна освіта", яке, на думку автора, складається 3 "виховання інтересу до культур інших народів, формування глобального мислення" [2, с. 179]. Таким чином, освітні програми полікультурної освіти повинні забезпечувати підвищення інтересу студентів приймаючої країни до особливостей культури іноземних учнів (що дозволить проводити більш успішну боротьбу з культурними уявленнями, що чинять негативний вплив на міжособистісні відносини в полікультурному суспільстві). У свою чергу, якщо іноземні студенти будуть зацікавлені в дослідженні культурних принципів приймаючого соціуму, вони отримають можливість більш швидкого проходження акультураційного процесу.

Що стосовно глобального мислення, при правицьному застосуванні технології полікультурного освіти, студенти формують навички соціокультурного та міжособистісного плану, а це дозволить їм надалі взаємодіяти 3 представниками різних країн, що в умовах глобалізації має позитивний вплив на конкурентоспроможність особистості до якісної діяльності в рамках сучасних міжнародних відносин.

Необхідно також розглянути визначення мети глобальної освіти, яка, згідно Педагогічного термінологічного словника, полягає

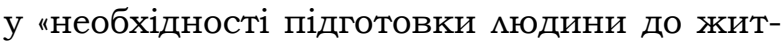
тя у взаємопов'язаному багатокультурному світі" [3]. Таким чином, полікультурна освіта безпосередньо впливає на адаптаційні процеси особистості та готує її до міжкультурної діяльності в трьох основних напрямках, а саме мінгвістичному (що впливає на ефективність комунікативної діяльності), культурному (робить вплив на прийняття культурних норм представників іншої держави) і психологічному (що спрямований на подомання стресових ситуацій, викликаних культурним шоком).

Таким чином, згідно 3 наведеними характеристиками, ми можемо надати своє формулювання поняття полікультурної освіти, як системи, метою якої є створення умов дмя ефективної міжособистісної та міжкультурної взаємодії між представниками різних соціокультурних груп, що дозволяє розвивати навички комунікативного плану.

Крім того, в понятті "технологія полікумьтурної освіти" важливе місце, на нашу думку, займає термін "технологія". Так, згідно з висновками Ф. Хадлом, технологія - це "розробка і суспільне використання інформації" [4, с. 35], що характеризується застосуванням освітніх підготовчих програм в практичній діяльності консультаційних центрів і при наданні відкритого доступу до такого роду матеріалів за допомогою використання медіа ресурсів. У свою чергу, О. Давидюк [5] у своїй дисертації приходить до визначення технології як об'єкта, що здатний ставати частиною виробничого процесу, набуваючи, одночасно 3 цим, риси інноваційності. Тому, ми можемо говорити, що технологія (коли мова йде про полікультурну освіту) передбачає практичне застосування інноваційних адаптаційних програм в рамках підготовчого процесу.

Варто звернути увагу на визначення Д. Адамюк, в рамках якого технологія визначається як "складний результат інтелектуальної діяльності» [4, с. 37], який, згодом, «застосовується при організації й функціонуванні конкретного виробничого процесу" [4, с. 37]. В даному випадку, також простежується спрямованість технологічного процесу саме на виробничий процес, у на- 
шому дослідженні - процес освітньої діяльності.

Таким чином, ми можемо охарактеризувати поняття "технологія" в якості виробничого процесу, що забезпечує практичне застосування інноваційних методик.

У підсумку, поняття "полікультурна освіта" i "технологія" надають нам можливість формулювання визначення терміну "техномогія полікультурної освіти", яка виділяється нами в якості практичного застосування інноваційних адаптаційних програм, спрямованих на формування та розвиток навичок міжкультурної взаємодії між представниками двох або більше культурних груп.

Виділена нами термінологічна база дозвоцяє говорити про технології, як процес, що спрямований на практичну діяльність. Відповідно, для проведення аналізу ефективності технологій помікультурної освіти у закладах вищої освіти нам необхідно розгмянути саме виробниче (іншими словами, практично-спрямоване) застосування адаптаційних інновацій. Але для систематизації програмної складової, нам необхідно виявити також фактори, що впливають на полікультурну освіту.

Полікультурна освіта $\epsilon$ системою, що надає всім студентам рівні можливості в академічному та соціальному напрямках. При впровадженні полікультурних принципів в освітній процес, особлива увага повинна бути приділена програмам практичного формату [6], у рамках яких має відбуватися взаємодія між помікультурною тріадою, що створює зв'язки «іноземний студент-місцевий студент", "іноземний студент-іноземний студент", «іноземний студент-представник місцевої громади". У таких програмах необхідно враховувати наявність різних характеристик у кожного іноземного студента, як фізичних, так i інтелектуальних. Тому, полікультурна освіта повинна не тільки визначати існуючі особистісні відмінності іноземних студентів, але і враховувати їх при розробці та практичному впровадженні програм. Так, К. Коппемман [7] прийшов до висновку, що полікультурна освіта вкцючає в себе студентів, які мають расові, етнічні та націонацьні відмінності. Таким чином, технологія полікультурної освіти повинна включати в себе можливість проведення ефективних аналітичних дій, що допоможе в досягненні студентами успіху в академічному та соціальному напрямках.

У свою чергу, Дж. Бенкс та К. Бенкс [8] виділили п'ять основних факторів полікуцьтурної системи освіти. Першим фрактором є достатнє використання викладачами соціально-спрямованих прикладів 3 різних культур у своїх навчальних програмах при навчанні іноземних студентів. Цей фактор передбачає необхідність наявності зв'язків між теоретичним матеріалом і проведенням культурної практики за допомогою комунікативного аспекту, що може вкАючати в себе розповідь про культури інших країн і проведення, згодом, кумьтурноспрямованих дискусій зі студентами. Такого роду обговорення можуть поліпшити взаєморозуміння і повагу між представниками різних культурних груп.

Другим чинником $\epsilon$ процес конструювання знань, що передбачає вивчення та визначення соціокультурних особливостей студентами, що дозволить більш якісно трансформувати іх знання про інші культури [9]. Наприклад, викладач або консультант може дати завдання студентам пояснити будь-яке явище, що призведе до різних трактувань представниками різний культур. Висновком такої діяльності може стати пояснення, що полягає у впливі культурних норм особистості на конструювання знань про те чи інше явище.

Третій фактор передбачає зменшення культурних уявмень, що спрямовано на розвиток демократичних поглядів на взаємодію з представниками інших культур. Технологія полікультуралізму повинна забезпечувати розуміння наявності яскравих відмінних особливостей інших культур, які, не дивцячись на це, можуть бути частиною соціуму, що їх приймає. Зниження упереджень впливає на усунення $з$ боку студентів усталених уявцень про осіб, що представцяють конкретні національності [8].

Четвертий фактор характеризується застосуванням рівноправної педагогіки, що передбачає проведення практики щодо формування навичок міжкультурної взаємодії, враховуючи академічні успіхи студентів. Так, перш за все, найбільш ефективним є розподіл студентів за невеликим групам (кожна з яких повинна включати студентів з різною успішністю та культурними особливостями), що дозволить їм проводити взаємонавчання i переймати досвід один в одного. Відповідно, освітні програми повинні враховувати такі форми навчання, іншими словами, бути пристосованими для багатокультурних груп.

П'ятий фрактор передбачає безпосередню взаємодію академічного та соціального напрямків. Так, в закладах вищої освіти, де проходить навчання велика кількість представників різних рас і національностей, основним завданням викладачів та консультаційних центрів $€$ створення рівних академічних і соціальних можливостей дмя всіх учасників освітнього процесу [8]. Крім того, варто пам'ятати, що полікульту- 
рна освіта передбачає проведення соціокумьтурної роботи не тільки з боку закладів вищої освіти, а й громади, в якій проживають іноземні студенти. Відповідно до твердження Дж. Бенкс [9], всі п'ять факторів $є$ взаємопов'язаними і повинні застосовуватися в практиці полікультурної взаємодії.

Висновки i перспективи подальших розвідок. Полікультурність освіти забезпечує необхідність проведення адаптаційного процесу за напрямками, які забезпечать повноцінну діяльність особистості в академічному та соціальному середовищах, а саме підготовку мінгвістичного, культурного і психомогічного характеру. Крім того, адаптація передбачає розвиток принципів глобального мислення, за допомогою якого іноземний студент отримує можливість використовувати сформовані міжособистісні і соціокультурні навички в конкретних ситуаціях взаємодії з представниками іншого соціуму. У зв'язку з цим, можна видіАити основні прояви полікультурної освіти, що повинні застосовуватися в процесі акумьтураційної підготовки, а саме:

1. Використання, спільно з наданням практичних відомостей про особливості інших культур, практичних елементів, серед яких можуть використовуватися аудіовізуальні засоби;

2. Вибудовування культурних знань студентів таким чином, що забезпечить єдине трактування дій представників інших кумьтур та дозволить підготувати іноземних студентів до діяльності у єдиному культурному просторі приймаючої країни;

3. Проведення практичного закріплення отриманих знань як за допомогою перехресної адаптації (при взаємодії різних кумьтурних груп на етапі підготовки), так i при формуванні адаптаційних завдань, що забезпечать зв'язок між академічними та соціальними контактами особистості.

Подальші дослідження полікультурної освіти i адаптаційного процесу можуть бути присвячені аналізу існуючих підготовчих програм дАя іноземних студентів (Аінгвістичного, культурного та психологічного характеру) для визначення достатності використання в них принципів полікультурності освіти.
Список бібліографічних посимань

1. Большой психологический словарь. Спб.: ПраймЕВРОЗНАК, 2003. 672 c.

2. Безрукова В.С. Основы духовной культуры (энциклопедический словарь педагога). Екатеринбург, 2000. 937 c.

3. Педагогический терминологический смоварь. СПб, 2006. URL: https://rus-pedagogicaldict.slovaronline.com (дата звернення: 23.04.2020).

4. Адамюк Д.І. Поняття технології: становцення змісту та співвідношення з іншими суміжними поняттями. Право та інноваиійне суспільство. 2015. №1(4). C. 34-41.

5. Давидюк О.М. Технологія як об'єкт господарськоправового регулювання: дис. ... канд. юрид. наук: 12.00.04. Харків, 2009. 222 с.

6. Lucas A.G. Distinguishing between multicultural and global education: The challenge of conceptualizing and addressing the two fields. Clearing House, 2010. №83(6). P. 211-216.

7. Koppelman K. The great diversity debate: Embracing pluralism in school and society. New York: Teachers College Press, 2011. 208 p.

8. Banks J.A., Banks C.A.M. Multicultural education: Issues and perspectives. Hoboken, NJ: John Wiley \& Sons, Inc., 2009. $480 \mathrm{p}$.

9. Banks J.A. Multicultural education, transformative knowledge and action: Historical and Contemporary Perspectives. New York: Teachers College Press, 1996. 384 p.

\section{References}

1. Big psychological dictionary (2003). Saint Petersburg: Praym-YeVROZNAK. [in Rus.].

2. Bezrukova, V.S. (2000). The basics of spiritual culture (teacher's encyclopedic dictionary). Yekaterinburg. [in Rus.].

3. Pedagogical terminology dictionary (2006). Saint Petersburg. Retrieved 23.04.2020, from: https://ruspedagogical-dict.slovaronline.com [in Rus.].

4. Adamiuk, D.I. (2015). The concept of technology: the formation of content and relationships with other related concepts. Law and innovation society, 1(4): 3441. [in Ukr.].

5. Davydiuk, O.M. (2009). Technology as an object of economic and legal regulation (PhD dissertation in Law). Kharkiv, 222 p. [in Ukr.]

6. Lucas, A.G. (2010). Distinguishing between multicultural and global education: The challenge of conceptualizing and addressing the two fields. Clearing House, 83(6): 211-216. [in Eng.].

7. Koppelman, K. (2011). The great diversity debate: Embracing pluralism in school and society. New York: Teachers College Press. [in Eng.].

8. Banks, J.A., Banks, C.A.M. (2009). Multicultural education: Issues and perspectives. Hoboken, $\mathrm{NJ}$ : John Wiley \& Sons, Inc. [in Eng.]

9. Banks, J.A. (1996). Multicultural education, transformative knowledge and action: Historical and Contemporary Perspectives. New York: Teachers College Press [in Eng.]

\section{SLUTSKIY Yaroslav,}

$\mathrm{PhD}$ in Pedagogy, Head of the educational and methodological center, Donbas State College of Technology and Management

\section{THE FEATURES OF POLYCULTURAL EDUCATION IN THE PROCESS} OF FOREIGN STUDENT'S ADAPTATION

Summary. Introduction. The article deals with the essential characteristics of multicultural education, which should be applied to the modern methods of foreign student adaptive preparation, who interacts with the representatives of the new cultural environment.
Purpose. To explore the features of multicultural education aimed at foreign student's preparing for practical activities of academic and social nature.

Results. It is revealed that multicultural education is manifests in the peculiarities of persons, connections who are the representatives of different linguistic, ethnic or 
national groups. The concept of global thinking, that characterized by the ability of a foreign student to practically apply the existing socio-cultural skills and interpersonal activity, is considered. On the analysis of the researchers findings, the own interpretation of the concepts of "multicultural education" and "technology of multicultural education" is given.

Conclusion. On the base of theoretical study, we concluded that multicultural education provides the need of adaptation process in the ways that will ensure the full activity of the individual in the academic and social environments: the preparation of linguistic, cultural and psychological character. In addition, the adaptation involves the development of global thinking principles, through which a foreign student is able to use the formed interpersonal and sociocultural skills in a specific situations of interaction with representatives of another society. In this connection, it is possible to distinguish the main manifestations of multicultural education, which should be used in the process of acculturation preparation, such as: the use, with the practical information giving on the characteristics of other cultures, of practical elements, among which the audiovisual means may be used; the students' cultural knowledge developing in the way to ensure a uniform interpretation of the actions of other cultures representatives and will allow to prepare the foreign students for activities in the host country's cultural space; the practical consolidation of the acquired knowledge both through the cross-adaptation (with the interaction of different cultural groups during the preparation phase), and at the time of the formation of adaptation tasks that will provide a connection between the academic and social contacts of the individual.

Keywords: adaptation; foreign student; multicultural education; acculturation process; technology; academic and social activities.

Одержано редакиією 15.05.2020 Прийнято до публікаиї 24.04.2020 